\title{
The oldest record of gnathostome fossils from Greece: Chondrichthyes from the Lopingian of Hydra Island
}

\author{
Thodoris Argyriou, Carlo Romano, Jorge D. Carrillo-Briceño, \\ Morgane Brosse, and Richard Hofmann
}

\begin{abstract}
The Permian deposits of Hydra Island, Greece, have been known for over a century and host some of the best-studied and most diverse invertebrate assemblages of the ancient Paleotethys Ocean. However, until now, no Paleozoic fossils of jawed vertebrates had been reported from Greece. Recent fieldwork on Hydra Island brought to light rare cartilaginous fish remains, including a tooth belonging to an unknown hybodontiform shark, as well as an unidentifiable dermal denticle of an euselachian shark. Despite similarities with iconic Paleozoic and Mesozoic durophagous euselachians, the Hydriot tooth likely corresponds to a new species, but is provisionally left in open nomenclature until more material becomes available. The new chondrichthyan fossils from Hydra Island correspond to one of the few Lopingian (late Permian) occurrences known from the Paleotethys. Moreover, they constitute the oldest record of jawed-vertebrate fossils from Greece, predating younger occurrences by more than 50 million years.
\end{abstract}

Thodoris Argyriou. Paleontological Institute and Museum, University of Zurich, Karl-Schmid-Strasse 4, Zürich, 8006, Switzerland. thodoris.argyriou@pim.uzh.ch

Carlo Romano. Paleontological Institute and Museum, University of Zurich, Karl-Schmid-Strasse 4, Zürich, 8006, Switzerland. carlo.romano@pim.uzh.ch

Jorge D. Carrillo-Briceño. Paleontological Institute and Museum, University of Zurich, Karl-Schmid-Strasse 4, Zürich, 8006, Switzerland. jorge.carrillo@pim.uzh.ch

Morgane Brosse. Paleontological Institute and Museum, University of Zurich, Karl-Schmid-Strasse 4, Zürich, 8006, Switzerland. morgane.brosse@pim.uzh.ch

Richard Hofmann. Paleontological Institute and Museum, University of Zurich, Karl-Schmid-Strasse 4, Zürich, 8006, Switzerland; Leibniz Institut für Evolutions und Biodiversitätsforschung, Museum für Naturkunde, Invalidenstraße 43, Berlin, 10115, Germany. richard.hofmann@mfn-berlin.de

Keywords: late Permian; Paleotethys; fossil fish; Hybodontiformes; Hydra Island; Greece

Submission: 6 October 2016 Acceptance: 27 February 2017

Argyriou, Thodoris, Romano, Carlo, Carrillo-Briceño, Jorge D., Brosse, Morgane, and Hofmann, Richard. 2017. The oldest record of gnathostome fossils from Greece: Chondrichthyes from the Lopingian of Hydra Island. Palaeontologia Electronica 20.1.8A: 1-9 palaeo-electronica.org/content/2017/1769-permian-sharks-of-greece

Copyright: @ March 2017 Society of Vertebrate Paleontology. This is an open access article distributed under the terms of the Creative Commons Attribution License, which permits unrestricted use, distribution, and reproduction in any medium, provided the original author and source are credited.

creativecommons.org/licenses/by/4.0/ 


\section{INTRODUCTION}

The Permian Period ( 298-252 Ma) was a particularly important time interval for life on the planet, characterized by a series of global-scale environmental disturbances that climaxed at $\sim 252$ Ma with the most-severe end-Permian mass extinction event (Benton and Twitchett, 2003; Burgess et al., 2014). Despite the catastrophic impact of this mass extinction event for most groups (e.g., Benton and Twitchett, 2003), many osteichthyan clades as well as euselachians were less severely affected (Friedman and Sallan, 2012; Koot, 2013; Romano et al., 2016). Recent works have improved our understanding of the Permian chondrichthyan fossil record (Ginter et al., 2010; Hampe et al., 2013; Hodnett et al., 2013; Ivanov et al., 2013; Koot, 2013; Koot et al., 2013; Chahud and Petri, 2014; Ivanov and Lebedev, 2014; Ivanov et al., 2015), but the latter remains sporadic and less well known in comparison to that of the Triassic (Hampe et al., 2013; Koot, 2013; Koot et al., 2013 and references therein). This fact might bias interpretations about the timing of clade origins, impact of the end-Permian mass extinction on chondrichthyans and the hypothesized patterns of the Early Triassic biotic recovery.

The restricted occurrences of Paleozoic (Silurian-Permian) sedimentary rocks in Greece have attracted considerable scientific attention since their first discovery, more than a century ago (Renz, 1910). Several invertebrate assemblages have been described from exotic or autochthonous rocks, but until now conodonts were the only putative vertebrates reported (e.g., Nestell and Wardlaw, 1987; Groves et al., 2003; for more information on the ongoing discussion about conodont affinities see Donoghue et al., 2000; Turner et al., 2010; Murdock et al., 2013). Reif (1978) mentioned the presence of "hybodontid-type" dermal denticles in the Permian of Greece, but did not describe or figure any, nor did he provide any locality or repository information. Previous oldest ascertained gnathostome occurrences from the country include poorly preserved actinopterygian remains from the Lower Jurassic of Lefkada Island, Ionian Sea (Kottek, 1964). These are succeeded by Maastrichtian-Danian chondrichthyan and teleostean fossils from various localities around the country (Koch and Nikolaus, 1969; Trikolas, 2008; Cavin et al., 2012).

Recent fieldwork on Hydra Island by R.H. and colleagues has brought to light new invertebrate and vertebrate material. The latter, described in this work, comprises one chondrichthyan tooth and one dermal denticle, deriving from the same handsample. These fossils represent the oldest, unambiguous gnathostome occurrences of Greece, predating younger occurrences by more than 50 million years. Furthermore, this occurrence is a valuable addition to the poor Lopingian (late Permian) chondrichthyan record of the Paleotethys (Schaumberg, 1977; Ginter et al., 2010; Koot, 2013).

\section{GEOLOGICAL SETTING AND AGE}

Hydra Island is located in the northwestern margin of Myrtoon Basin, western Aegean Sea (Eastern Mediterranean), $\sim 70 \mathrm{~km}$ to the southsouthwest of Athens (Figure 1.1). The late Paleozoic outcrops, first reported by Renz (1910), are located along the southeastern coast of the island and comprise shallow water carbonate and siliciclastic successions (Figure 1.2-3), which were deposited on the northwestern Paleotethyan margin, forming the base of the "sub-Pelagonian" zone (Baud et al., 1990; Grant et al., 1991). A diverse array of fossils is known from the autochthonous Permian sedimentary successions of Hydra, including algae (Jenny et al., 2004), benthic foraminifera (Vachard et al., 1995; Jenny et al., 2004; Vachard et al., 2008), ostracods (Crasquin-Soleau and Baud, 1998; Kornicker and Sohn, 2000) and brachiopods (Grant, 1972, 1995; Shen and Clapham, 2009). Conodonts are mostly known from the upper part of the Lopingian limestone (Nestell and Wardlaw, 1987), where the successive occurrences of Neogondolella leveni and Neogondolella orientalis indicate a Wuchiapingian (early Lopingian) age (Kozur, 1975). The matrix surrounding the chondrichthyan fossils contained three conodont $\mathrm{P}_{1}$ elements, belonging to Hindeodus. The best-preserved one is assignable to Hindeodus typicalis, which has a Lopingian-lower Induan stratigraphic range. Since Induan (earliest Triassic) deposits are unknown from Hydra, our conodonts best indicate a Lopingian age for the studied sample.

\section{MATERIAL AND METHODS}

The chondrichthyan tooth was partly exposed on the surface of a hand-sample $(\sim 1.5 \mathrm{~kg})$ of silicified dark grey-colored limestone. The sample was dissolved in a 10\% buffered acetic acid (Jeppsson et al., 1999) and concentrated by heavy liquid separation (Jeppsson and Anehus, 1999). The residue was handpicked under a binocular microscope, and the recovered vertebrate material was imaged 


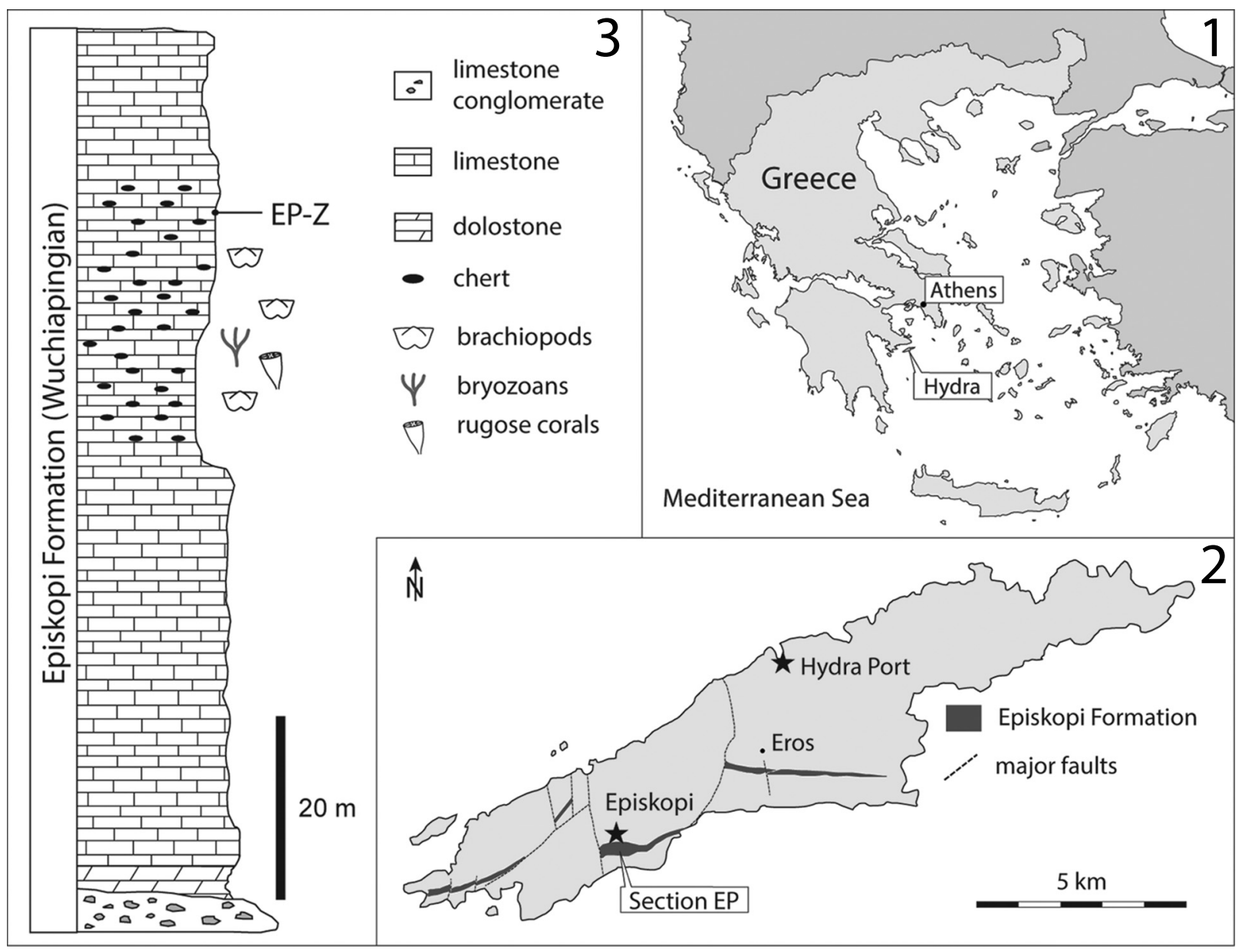

FIGURE 1. Geographical and geological context of the Hydriot chondrichthyan fossils. 1, Map of Greece showing the location of Hydra Island; 2, Outcrop map of Hydra Island showing the location of the sampled section "EP" south of the village of Episkopi. Outcrop map after Grant et al. (1991); 3, Stratigraphic section of the Episkopi Formation showing the provenance ("EP-Z") of the examined gnathostome fossils.

with a JSM-6010PLUS LA Scanning Electron Microscope at the Center for Microscopy and Image Analysis, University of Zurich (ZMBUZH). Both gnathostome specimens are catalogued and housed in the vertebrate collection of the Museum of Paleontology and Geology, National and Kapodistrian University of Athens, Greece (AMPG). Tooth and dermal denticle terminology applied herein adheres to that of previous works (Reif, 1978; Ginter et al., 2010; Cappetta, 2012). For comparative purposes we examined hybodontiform and Acronemus material from the Middle Triassic of Monte San Giorgio (Ticino, Switzerland), housed at the Paleontological Institute and Museum, University of Zurich, Switzerland (PIMUZ). For a complete list of specimens catalogued at the PIMUZ the reader is referred to Rieppel $(1981,1982)$ and Mutter (1998a, 1998b).

\section{SYSTEMATIC PALEONTOLOGY}
Class CHONDRICHTHYES Huxley, 1880
Cohort EUSELACHII Hay, 1902

Order HYBODONTIFORMES Maisey, 1975

Hybodontiformes Gen. et sp. indet.

Figure 2.1-5

Material. One tooth of indeterminate jaw position, AMPG 550.

Description. The crushing-type tooth is characterized by a well-preserved crown and a somewhat damaged root. The isolated nature of the tooth allows only a tentative attribution of one of the two broad lateral surfaces to labial, based on the combination of a well-defined root sulcus accommodating a single row of foramina, as well as the lingual inclination of the underlying root surface.

The crown bears a single, low and rounded main cusp. In occlusal view (Figure 2.1) the crown 

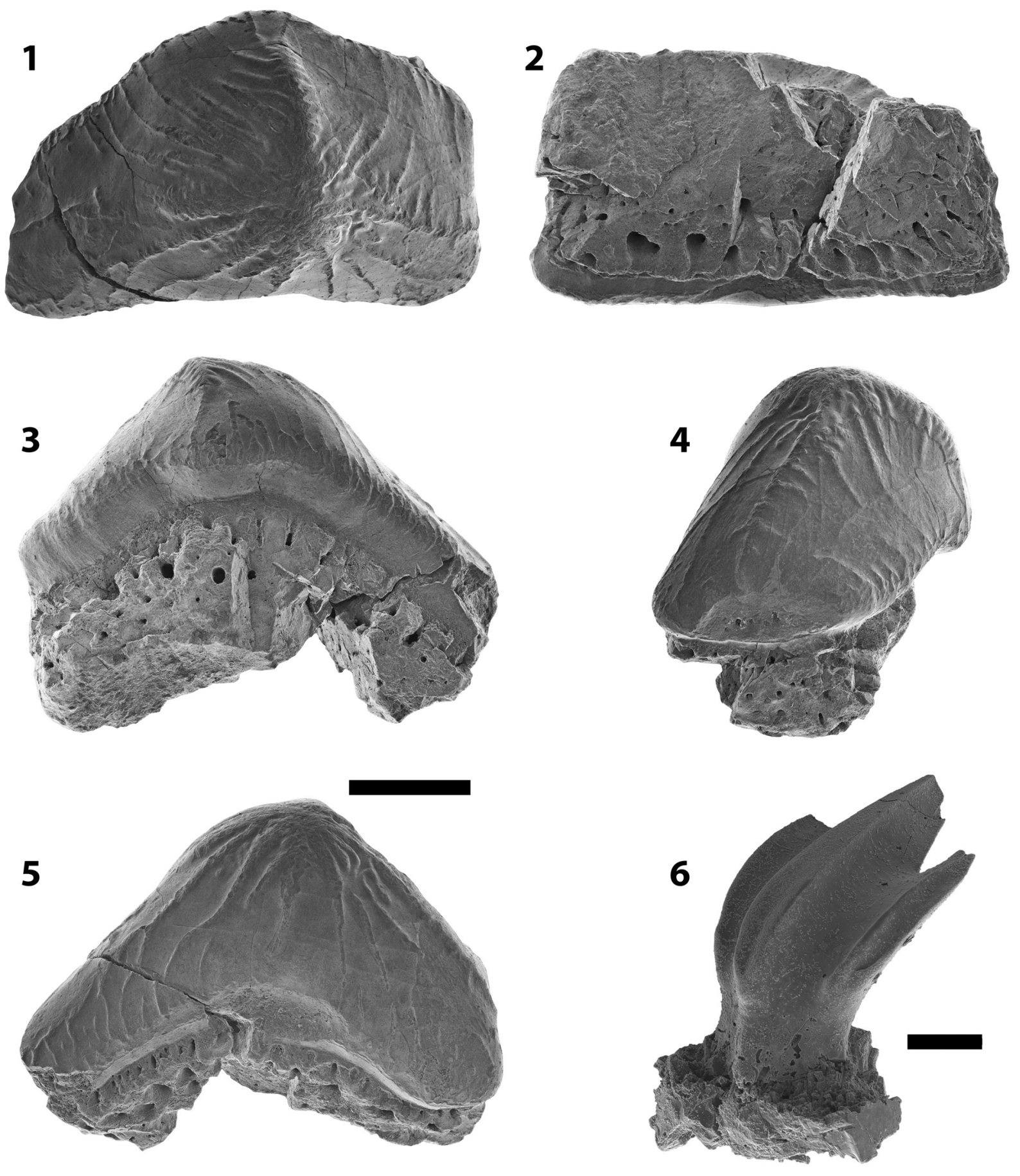

FIGURE 2. Chondrichthyan material from Hydra. 1-5, Hybodontiformes indet. tooth (AMPG 550) in occlusal (1), basal (2), presumed lingual (3), profile (4), and presumed labial (5) views. Scale bar equals $5 \mathrm{~mm}$. 6, Euselachii indet. dermal denticle (AMPG 551) in anterolateral view. Scale bar equals $100 \mu \mathrm{m}$. 
is triangular with truncated mesial and distal edges. It overhangs the root almost completely and forms a distinct presumably lingual projection. The crown bears a distinct labiolingual crest and a less distinct mesiodistal crest, the two meeting at an almost right angle, on the apex of the main cusp. The mesiodistal crest fades before reaching the edges of the crown. Most delicate secondary, crests radiate from the junction point of the two primary crests, while few originate from the labiolingual and mesiodistal crests, near their junction. Few secondary crests run continuously until the base of the crown where they might bifurcate. Others fade midway to reappear near the base of the crown. When viewed lingually or labially, the crown is boomerang-shaped. The lingual surface is convex (Figure 2.3), bearing a well-developed, median, laterobasally directed protuberance. The presumed concave labial surface bears fewer secondary crests and is characterized by a socket-like elliptical hollow (Figure 2.5), presumably for accommodating the lingual protuberance of the neighboring tooth of the same file, indicating some weak imbrication of the dentition.

The anaulacorhize root is apicobasally, mesiodistally, and labiolingually shorter than the crown and conforms to its contour. In lingual view (Figure 2.3), the root is damaged, but is populated by randomly arranged, apicobasally elongate foramina. In labial view (Figure 2.5), the root is markedly shallow, less than one fourth of the crown height. The labial face of root bears a weak sulcus along the crown-root margin, populated by a single row of well-arranged, apicobasally elongate foramina, smaller and more numerous ( 20) than those of the other lateral face. The basal half of the root is slanted lingually, bearing larger, sparsely arranged, enlarged foramina. The base of the root, although damaged, appears flat and sub-rectangular, without a distinct lingual protuberance. In profile view (Figure 2.4), the crown clearly overhangs the root.

Remarks. Several Paleozoic and Mesozoic chondrichthyans have convergently evolved low crowned, crushing-type teeth. However, the presence of a single cusp, the ridged crown ornamentation and the anaulacorhize root anatomy, which includes a distinct sulcus with specialized foramina along the crown-root boundary, compare favorably to features seen in durophagous euselachians (e.g., Ginter et al., 2010; Cappetta, 2012). Isolated teeth of Paleozoic and early Mesozoic stem euselachians, hybodontiforms and stem neoselachians are often difficult to distinguish and attribute to less inclusive groups, due to their generalized and/or often homoplasic morphologies (Ginter et al., 2010; Cappetta, 2012). Despite this fact, a review of dental anatomy of Paleozoic-early Mesozoic forms can provide some information about the systematic affinities of the Hydriot tooth.

Macroscopic teeth of Paleozoic-early Mesozoic stem neoselachians exhibit crowns with welldefined median cusps and, when present, accessory cusplets and/or a median cutting edge (Ginter et al., 2010; Koot et al., 2013). Their roots are either hemiaulacorhize or pseudo-polyaulacorhize; they typically bear fewer, enlarged foramina (the median ones in particular) than other euselachians; and are somewhat arcuate in basal view, due to the presence of a lingual protuberance (Ginter et al., 2010). None of the above is seen in the examined specimen, rendering a neoselachian attribution unfavorable. Low-crowned crushing teeth without lateral cusplets, but with anaulacorhize, multiforaminate roots, which often include a labial sulcus accommodating a single row of specialized foramina, are seen in members of the Hybodontiformes (e.g., Acrodus; Lissodus; Omanoselache; Onychoselache) as well as in the stem euselachian (sensu Maisey, 2011) Acronemus (Johnson, 1981; Rieppel, 1982; Ginter et al., 2010; Cappetta, 2012; Koot et al., 2013, 2015).

Hybodontiformes can exhibit very disparate dental features, and are formally united as a group by means of cranial and postcranial anatomy (Maisey, 1975, 1982; Ginter et al., 2010; Cappetta, 2012). Within the Paleozoic-Triassic Hybodontiformes, dental anatomy somewhat comparable to that of our specimen occurs in Acrodus, Lissodus, Hamiltonichthys, and Onychoselache (e.g., Ginter et al., 2010; Cappetta, 2012). Despite the uncertain affinities of Acronemus within euselachians, its tooth morphology is hybodontiform-like (Rieppel, 1982; Maisey, 2011; Cappetta, 2012), and resemblant to that of AMPG 550. One of the most conspicuous differences among the abovementioned genera is the occurrence of a lingual crown protuberance in Hamiltonichthys (Maisey, 1989), Onychoselache (Coates and Gess, 2007) and Acronemus (Rieppel, 1982), rather than a labial one as in most other Hybodontiformes.

The single, blunt main cusp and the ridged ornamentation are common features of Acrodontidae (sensu Cappetta, 2012). Acrodus (s.l.) is the only member of the family that shows resemblances to our specimen and has Paleozoic occurrences (as ?Acrodus) (Johnson, 1981; Hodnett et al., 2011; Hampe et al., 2013). It is otherwise prom- 
inently known from Triassic (e.g., Rieppel, 1981; Mutter, 1998a, 1998b; Cappetta, 2012) and younger Mesozoic deposits (Cappetta, 2012). Acrodus teeth exhibit marked monognathic heterodonty, with symphyseal, parasymphyseal and posterior teeth being mesiodistally narrower and more apicobasally arcuate than lateral teeth (Mutter, 1998a; Ginter et al., 2010; Cappetta, 2012), resembling the Hydriot tooth. However, Acrodus teeth bear a distinct mesiodistal crest and a less distinct or absent labiolingual crest (Johnson, 1981; Rieppel, 1981; Mutter, 1998a, 1998b; Ginter et al., 2010; Hodnett et al., 2011; Cappetta, 2012; Hampe et al., 2013). In addition, secondary crests initiate all along the horizontal crest, are tightly packed and exhibit strong bifurcation patterns, whereas a socket for tooth interlocking is absent in most species (Johnson, 1981; Rieppel, 1981; Mutter, 1998a, 1998b; Ginter et al., 2010; Hodnett et al., 2011; Cappetta, 2012; Hampe et al., 2013), except in A. georgii, where it is situated lingually (Mutter, 1998b). The abovementioned differences preclude the inclusion of the Hydra chondrichthyan in Acrodus.

Teeth of the Pennsylvanian genus Hamiltonichthys resemble the Hydriot tooth in terms of occlusal crown ornamentation, while they also bear a lingual protuberance and a labial scar (Maisey, 1989). Our specimen differs from Hamiltonichthys in exhibiting more rounded corners at the mesial and distal end of the crown in occlusal view. Onychoselache (Coates and Gess, 2007) exhibits teeth of more subtle crown ornamentation and higher roots than AMPG 550. Finally, unicuspidate Lissodus teeth have strongly lingually bent roots, whereas mesiodistal and labiolingual occlusal crests form more pronounced, sharp, and often jagged, cutting edges (Rees and Underwood, 2002; Duncan, 2004; Ginter et al., 2010). The marked labiolingual crest on the crown of AMPG 550 , the lingual bulbous crown projection, along with the wider spacing between the secondary ridges are also reminiscent of characteristics of medial teeth of the ?Pennsylvanian-Middle Triassic Acronemus (Euselachii incertae sedis) (Rieppel, 1982; Rees and Underwood, 2002; Maisey, 2011). Despite the presence of a distinct lingual protuberance, Acronemus teeth do not possess a labial socket, differing in that regard from the Hydriot tooth. Acronemus teeth are further differentiated by their height and their shorter, strongly saddle-shaped crown (Rieppel, 1982). Unfortunately, little is known about root vascularization in Acronemus teeth.
A close relationship between AMPG 550 and the Triassic Palaeobates or Homalodontus (= "Wapitiodus"), both possessing flat-crowned teeth, is excluded based on the general tooth morphology and ornamentation (Mutter et al., 2007, 2008; Romano and Brinkmann, 2010). The potential Permian stem euselachian Wodnika possess a smooth crown, markedly dissimilar to that of the Hydriot specimen (Haubold and Schaumberg, 1985; Hampe in Cappetta, 2012). Finally, the unicuspidate teeth of the hybodontiform Omanoselache differ in ornamentation, shape, and direction of crown protuberance and exhibit fewer but larger root foramina (Koot et al., 2013, 2015).

In summary, AMPG 550 shows moderate to strong morphological affinities with Hamiltonichthys, Acronemus and moderate affinities with Paleozoic ?Acrodus teeth of Johnson (1981). However, conspicuous differences in crown shape and ornamentation, interlocking process and root development preclude its assignment to any of the aforementioned genera. Our small sample size does not permit the erection of a new genus and, on the basis of dental characteristics alone, we prefer to leave it in open nomenclature within Hybodontiformes until additional fossil material becomes available.

\section{Cohort EUSELACHII Hay, 1902 \\ Euselachii indet.}

Figure 2.6

Material. One fragmented dermal denticle, AMPG 551.

Description. The relatively well-preserved crown is lanceolate and curved posteriorly. It possesses a well-developed, tricuspid distal crown, a neck and a base. Three keels can be seen on the anterodistal part of the crown. The median keel bears a shallow groove along its basal half and is distinctly higher than the two lateral keels. Its proximal end continues as a gentle ridge on the anterior surface of the neck. The lateral keels are grooved along their length and splay dorsolaterally, in anterior view. The neck is slightly narrower than the crown. The base is poorly preserved, but must have had a triangular outline and is wider than the crown, in proximal view.

Remarks. The presence of a slender crown with three keels on its anterior surface and a narrow neck are common features in scales of PaleozoicMesozoic ctenacanthids, but are also common in euselachian chondrichthyans (Reif, 1978; Hansen, 1986; Rieppel et al., 1996; Johns et al., 1997; Derycke-Khatir et al., 2005; Ivanov et al., 2013). The Hydriot denticle compares favorably to the par- 
agenus Moreyella (Gunnell, 1933; Hansen, 1986), which has been tentatively affiliated with Carboniferous-Permian hybodontiform chondrichthyans (e.g., Derycke-Khatir et al., 2005). The Triassic paragenera Fragilicorona and Labascicorona (Johns et al., 1997) also display very similar, tricuspid distal crowns like the denticle in question, but their systematic affinities beyond the euselachian level have not been discussed (Ivanov et al., 2013). Hybodontiform dermal denticles can exhibit disparous morphologies, even in the same individual, ranging from somewhat stockier and shorter types with more keels and stout or undeveloped necks (Reif, 1978), to more delicate and elongate ones like AMPG 551. Denticles of the latter type cannot be effectively distinguished from those of other euselachians (Rieppel et al., 1996; Ivanov et al., 2013). Thus, it is unclear whether the Hydra denticle comes from the same genus or individual as the tooth AMPG 550.

\section{CONCLUSION}

The new chondrichthyan material from the Wuchiapingian (Early Lopingian) of Hydra Island represents the oldest gnathostome remains of Greece, and adds a new occurrence to the relatively poor late Permian fish fossil record (Koot, 2013; Romano et al., 2016). Coeval occurrences from the western Paleotethys are mainly known from Western and Central Europe (Koot, 2013). The presence of bed-controlled chondrichthyan microremains associated with conodont index fossils emphasizes the importance of the new locality and future fieldwork on Hydra could further improve our knowledge about chondrichthyan faunas a few million years before the largest mass extinction event. The Hydriot tooth presented herein shows particular resemblances to iconic Paleozoic (Hamiltonichthys) and Paleozoic-Mesozoic taxa (Acrodus, Acronemus), but likely belongs to a new genus and species that could prove important for the resolution of hybodontiform and euselachian phylogeny. However, additional fossil material is required for a more conclusive systematic interpretation. The discovery of Permian chondrichthyans in Hydra highlights the need for additional paleontological survey in the pre-Cenozoic, and especially the Paleozoic, deposits of Greece.

\section{ACKNOWLEDGMENTS}

The authors wish to thank the two anonymous reviewers and the editorial team of Palaeontologia
Electronica for their insightful comments that improved the quality of this manuscript. Special thanks to M. Kirschmann (ZMBUZH) for assisting the SEM imaging process; R. Kindlimann (Switzerand) for providing useful comments during the early stages of the work and M. Leu (PIMUZ) for helping with acid preparation of hand samples. We are indebted to M.R. Sánchez-Villagra and $M$. Hautmann (both PIMUZ) for their support during the preparation of this study. M. Haas $(E T H$, Zürich) is thanked for field assistance and S. Roussiakis (AMPG) for providing specimen numbers. Access to the field localities and sampling permission was provided by the Hellenic Ministry of Culture and Sports, and the AMPG.

\section{REFERENCES}

Baud, A., Jenny, C., Papanikolaou, D., Sideris, C., and Stampfli, G. 1990. New observations on Permian stratigraphy in Greece and geodynamic interpretation. Bulletin of the Geological Society of Greece, 25(1):187-206.

Benton, M.J. and Twitchett, R.J. 2003. How to kill (almost) all life: the end-Permian extinction event. Trends in Ecology \& Evolution, 18(7):358-365.

Burgess, S.D., Bowring, S., and Shen, S.-Z. 2014. Highprecision timeline for Earth's most severe extinction. Proceedings of the National Academy of Sciences, 111(9):3316-3321.

Cappetta, H. 2012. Chondrichthyes II: Mesozoic and Cenozoic Elasmobranchii, p. 512. In Schultze, H.P. (ed.), Handbook of Paleoichthyology, vol. 3B. Dr. Friedrich Pfeil, München.

Cavin, L., Alexopoulos, A., and Piuz, A. 2012. Late Cretaceous (Maastrichtian) ray-finned fishes from the island of Gavdos, southern Greece, with comments on the evolutionary history of the aulopiform teleost Enchodus. Bulletin de la Société Géologique de France, 183(6):561-572.

Chahud, A. and Petri, S. 2014. New chondrichthyans from the Irati Formation (Early Permian, Paraná Basin), Brazil: origin, paleoenvironmental and paleogeographical considerations. Proceedings of the Geologists' Association, 125(4):437-445.

Coates, M.I. and Gess, R.W. 2007. A new reconstruction of Onychoselache traquairi, comments on early chondrichthyan pectoral girdles and hybodontiform phylogeny. Palaeontology, 50(6):1421-1446.

Crasquin-Soleau, S. and Baud, A. 1998. New Permian ostracods from Greece (Hydra Island). Journal of Micropalaeontology, 17(2):131-152.

Derycke-Khatir, C., Vachard, D., Dégardin, J.-M., Flores de Dios, A., Buitrón, B., and Hansen, M. 2005. Late Pennsylvanian and Early Permian chondrichthyan microremains from San Salvador Patlanoaya (Puebla, Mexico). Geobios, 38(1):43-55. 
Donoghue, P.C.J., Forey, P.L., and Aldridge, R.J. 2000. Conodont affinity and chordate phylogeny. Biological Reviews, 75(2):191-251.

Duncan, M. 2004. Chondrichthyan genus Lissodus from the Lower Carboniferous of Ireland. Acta Palaeontologica Polonica, 49(3):417-428.

Friedman, M. and Sallan, L.C. 2012. Five hundred million years of extinction and recovery: a Phanerozoic survey of large-scale diversity patterns in fishes. Palaeontology, 55(4):707-742.

Ginter, M., Hampe, O., and Duffin, C. 2010. Chondrichthyes. Paleozoic Elasmobranchii: Teeth. Handbook of Paleoichthyology, 3D. Dr. Friedrich Pfeil, München.

Grant, R.E. 1972. The Lophophore and Feeding Mechanism of the Productidina (Brachiopoda). Journal of Paleontology, 46(2):213-248.

Grant, R.E. 1995. Upper Permian brachiopods of the superfamily Orthotetoidea from Hydra Island, Greece. Journal of Paleontology, 69(04):655-670.

Grant, R.E., Nestell, M.K., Baud, A., and Jenny, C. 1991. Permian stratigraphy of Hydra Island, Greece. Palaios, 6(5):479-497.

Groves, J.R., Larghi, C., Nicora, A., and Rettori, R. 2003. Mississippian (Lower Carboniferous) microfossils from the Chios Mélange (Chios Island, Greece). Geobios, 36(4):379-389.

Gunnell, F.H. 1933. Conodonts and fish remains from the Cherokee, Kansas City, and Wabaunsee Groups of Missouri and Kansas. Journal of Paleontology, 7(3):261-297.

Hampe, O., Hairapetian, V., Dorka, M., Witzman, F., Akbari, A.M., and Korn, D. 2013. A first Late Permian fish fauna from Baghuk Mountain (Neo-Tethyan shelf, central Iran). Bulletin of Geosciences, 88(1):120.

Hansen, M.C. 1986. Microscopic chondrichthyan remains from Pennsylvanian marine rocks of Ohio and adjacent areas, Unpublished PhD Thesis, The Ohio State University, Columbus, Ohio, USA.

Haubold, H. and Schaumberg, G. 1985. Die Fossilien des Kupferschiefers. A. Ziemsen, Wittenberg Lutherstadt.

Hay, O.P. 1902. Bibliography and catalogue of fossil Vertebrata of North America. Bulletin of the United States Geological Survey, 179:1-868.

Hodnett, J.-P., Elliott, D.K., and Olsen, T. 2011. The hybodontiform sharks (Chondrichthyes) from the marine Permian (Leonardian) Kaibab Formation of northern Arizona. Ichthyolith Issues, Special Publication, 12:23-24.

Hodnett, J.-P., Elliott, D.K., and Olson, T.J. 2013. A new basal hybodont (Chondrichthyes, Hybodontiformes) from the middle Permian (Roadian) Kaibab Formation, of Northern Arizona, p. 103-108. In Lucas, S.G., DiMichele, W.A., Barrick, J.E., Schneider, J.W., and Spielmann, J.A. (eds.), The Carboniferous-Permian Transition. New Mexico Museum of Natural History and Science, Bulletin. New Mexico Museum of Natural History, Albuquerque.

Huxley, T.H. 1880. On the application of the laws of evolution to the arrangement of the Vertebrata, and more particularly of the Mammalia. Proceedings of the Scientific Meetings of the Zoological Society of London, 1880:649-662.

Ivanov, A.O. and Lebedev, O.A. 2014. Permian chondrichthyans of the Kanin Peninsula, Russia. Paleontological Journal, 48(9):1030-1043.

Ivanov, A.O., Nestell, G.P., and Nestell, M.K. 2013. Fish assemblage from the Capitanian (Middle Permian) of the Apache Mountains, West Texas, USA, p. 152160. In Lucas, S.G., DiMichele, W.A., Barrick, J.E., Schneider, J.W., and Spielmann, J.A. (eds.), The Carboniferous-Permian transition. New Mexico Museum of Natural History \& Science, Albuquerque, New Mexico, USA.

Ivanov, A.O., Nestell, M.K., and Nestell, G.P. 2015. Middle Permian fish microremains from the early Capitanian of the Guadalupe Mountains,West Texas, USA. Micropaleontology, 61:301-312.

Jenny, C., Izart, A., Baud, A., and Jenny, J. 2004. Le Permien de l'île d'Hydra (Grèce), micropaléontologie, sédimentologie et paléoenvironnements. Revue de Paléobiologie, 23(1):275-312.

Jeppsson, L. and Anehus, R. 1999. A new technique to separate conodont elements from heavier minerals. Alcheringa: An Australasian Journal of Palaeontology, 23(1):57-62.

Jeppsson, L., Anehus, R., and Fredholm, D. 1999. The Optimal Acetate Buffered Acetic Acid Technique for Extracting Phosphatic Fossils. Journal of Paleontology, 73(5):964-972.

Johns, M.J., Barnes, C.R., and Orchard, M.J. 1997. Taxonomy and Biostratigraphy of the Middle and Late Triassic elasmobranch ichthyoliths from Northeastern British Columbia Canadian government publishing, Ottawa, Ontario, Canada.

Johnson, G.D. 1981. Hybodontoidei (Chondrichthyes) from the Wichita-Albany Group (Early Permian) of Texas. Journal of Vertebrate Paleontology, 1(1):1-41.

Koch, K.E. and Nikolaus, H.J. 1969. Zur Geologie des Ostpindos - Flyschbeckens und seiner Umrandung, Institute for Geology and Subsurface Research, Athens.

Koot, M.B. 2013. Effects of the late Permian mass extinction on chondrichthyan palaeobiodiversity and distribution patterns, Unpublished PhD Thesis, Plymouth University, Plymouth, UK. Available at https:// pearl.plymouth.ac.uk/handle/10026.1/1584.

Koot, M.B., Cuny, G., Orchard, M.J., Richoz, S., Hart, M.B., and Twitchett, R.J. 2015. New hybodontiform and neoselachian sharks from the Lower Triassic of Oman. Journal of Systematic Palaeontology, 13(10):891-917.

Koot, M.B., Cuny, G., Tintori, A., and Twitchett, R.J. 2013. A new diverse shark fauna from the Wordian (Middle Permian) Khuff Formation in the interior 
Haushi-Huqf area, Sultanate of Oman. Palaeontology, 56(2):303-343.

Kornicker, L.S. and Sohn, I.G. 2000. Myodocopid Ostracoda from the late Permian of Greece and a basic classification for Paleozoic and Mesozoic Myodocopida. Smithsonian Contributions to Paleobiology, 91:1-33.

Kottek, A. 1964. Fischreste aus dem griechischen Lias. Annales géologiques de pays hélleniques, 39:175 - 181+1 tab.

Kozur, H. 1975. Beiträge zur Conodontenfauna des Perm. Geologisch-Paläontologische Mitteilungen Innsbruck, 5(4):1-44+4pls.

Maisey, J.G. 1975. The interrelationships of phalacanthus selachians. Neues Jahrbuch für Geologie und Paläontologie - Abhandlungen, 9:553-565.

Maisey, J.G. 1982. The anatomy and interrelationships of Mesozoic hybodont sharks. American Museum Novitates, 2724:1-48.

Maisey, J.G. 1989. Hamiltonichthys mapesi, g. \& sp. nov. (Chondrichthyes; Elasmobranchii), from the Upper Pennsylvanian of Kansas. American Museum Novitates, 2931:1-42.

Maisey, J.G. 2011. The braincase of the Middle Triassic shark Acronemus tuberculatus (Bassani, 1886). Palaeontology, 54(2):417-428.

Murdock, D.J.E., Dong, X.-P., Repetski, J.E., Marone, F., Stampanoni, M., and Donoghue, P.C.J. 2013. The origin of conodonts and of vertebrate mineralized skeletons. Nature, 502(7472):546-549.

Mutter, R.J. 1998a. Tooth variability and reconstruction of dentition in Acrodus sp. (Chondrichthyes, Selachii, Hybodontoidea) from the Grenzbitumenzone (Middle Triassic) of Monte San Giorgio (Ticino, Switzerland). Geologia Insubrica, 3(1):23-31.

Mutter, R.J. 1998b. Zur systematischen Stellung einer Bezahnungsreste von Acrodus georgii sp. nov. (Selachii,Hybodontoidea) aus der Grenzbitumenzone (Mittlere Trias) des Monte San Giorgio (Kanton Tessin, Schweiz). Eclogae Geologicae Helvetiae, 91:513519.

Mutter, R.J., de Blanger, K., and Neuman, A.G. 2007. Elasmobranchs from the Lower Triassic Sulphur Mountain Formation near Wapiti Lake (BC, Canada). Zoological Journal of the Linnean Society, 149:309337.

Mutter, R.J., Neuman, A.G., and de Blanger, K. 2008. Homalodontus nom. nov., a replacement name for Wapitiodus Mutter, de Blanger and Neuman, 2007 (Homalodontidae nom. nov., ?Hybodontoidea), preoccupied by Wapitiodus Orchard, 2005. Zoological Journal of the Linnean Society, 154:419-420.

Nestell, M.K. and Wardlaw, B.R. 1987. Upper Permian conodonts from Hydra, Greece. Journal of Paleontology, 61(04):758-772.

Rees, J. and Underwood, C.J. 2002. The status of the shark genus Lissodus Brough, 1935, and the position of nominal Lissodus species within the Hybodon- toidea (Selachii). Journal of Vertebrate Paleontology, 22(3):471-479.

Reif, W.-E. 1978. Types of morphogenesis of the dermal skeleton in fossil sharks. Paläontologische Zeitschrift, 52(1):110-128.

Renz, C. 1910. Stratigraphische Untersuchungen im griechischen Mesozoikum und Paläozoikum. Jahrbuch der Kaiserlich Königlichen Geologischen Reichsanstalt, 60(3):57-87.

Rieppel, O. 1981. The hybodontiform sharks from the Middle Triassic of Mte. San Giorgio, Switzerland. Neues Jahrbuch für Geologie und Paläontologie Abhandlungen, 161(3):324-353.

Rieppel, O. 1982. A new genus of shark from the Middle Triassic of Monte San Giorgio, Switzerland. Palaeontology, 25(2):399-412.

Rieppel, O., Kindliman, R., and Bucher, H. 1996. A new fossil fish fauna from the Middle Triassic (Anisian) of North-Western Nevada, p. 501-512. In Arratia, G. and Viohl, G. (eds.), Mesozoic Fishes - Systematics and Paleoecology. Dr. Friedrich Pfeil, München, Germany.

Romano, C. and Brinkmann, W. 2010. A new specimen of the hybodont shark Palaeobates polaris with threedimensionally preserved Meckel's cartilage from the Smithian (Early Triassic) of Spitsbergen. Journal of Vertebrate Paleontology, 30(6):1673-1683.

Romano, C., Koot, M.B., Kogan, I., Brayard, A., Minikh, A.V., Brinkmann, W., Bucher, H., and Kriwet, J. 2016. Permian-Triassic Osteichthyes (bony fishes): diversity dynamics and body size evolution. Biological Reviews, 91(1):106-147.

Schaumberg, E. 1977. Der Richelsdorfer Kupferschiefer und seine Fossilien, III. Die tierischen Fossilien des Kupferschiefers 2. Vertebraten. der Aufschluss, 28:297-352.

Shen, S.-Z. and Clapham, M.E. 2009. Wuchiapingian (Lopingian, late Permian) brachiopods from the Episkopi Formation of Hydra Island, Greece. Palaeontology, 52(4):713-743.

Trikolas, N. 2008. Geological study of the wider area of Aegialia and Kalavryta, Unpublished PhD Thesis, National Technical University of Athens, Athens, Greece. (In Greek)

Turner, S., Burrow, C.J., Schultze, H.-P., Blieck, A., Reif, W.-E., Rexroad, C.B., Bultynck, P., and Nowlan, G.S. 2010. False teeth: conodont-vertebrate phylogenetic relationships revisited. Geodiversitas, 32(4):545-594.

Vachard, D., Martini, R., and Zaninetti, L. 1995. Le Murgabien á Fusulinoides des iles d'Hydra, Crète et Mytilène (Permien supérieur de Grèce). Geobios, 28(4):395-406.

Vachard, D., Rettori, R., Angiolini, L., and Checconi, A. 2008. Glomomidiella gen. n. (Foraminifera, Miliolata, Neodiscidae): a new genus from the late Guadalupian-Lopingian of Hydra Island. Rivista Italiana di Paleontologia e Stratigrafia, 114(3):349-361+2 pls. 